\title{
4: 75675888-75685761
}

National Cancer Institute

\section{Source}

National Cancer Institute. 4: 75675888-75685761. NCI Thesaurus. Code C41711.

Physical location of AREG_Gene 